University of Nebraska - Lincoln

DigitalCommons@University of Nebraska - Lincoln

Faculty Publications: Department of Entomology

Entomology, Department of

April 2006

\title{
Inheritance of Resistance to the Cry1 Ab Bacillus thuringiensis Toxin in Ostrinia nubilalis (Lepidoptera: Crambidae)
}

\author{
Analiza P. Alves \\ University of Nebraska-Lincoln, apiovesanalves2@unl.edu \\ Terrence A. Spencer \\ University of Nebraska-Lincoln, tspencer1@unl.edu \\ B.E. Tabashnik \\ University of Nebraska-Lincoln \\ Blair Siegfried \\ University of Nebraska-Lincoln, bsiegfried1@ufl.edu
}

Follow this and additional works at: https://digitalcommons.unl.edu/entomologyfacpub

Part of the Entomology Commons

Alves, Analiza P.; Spencer, Terrence A.; Tabashnik, B.E.; and Siegfried, Blair, "Inheritance of Resistance to the Cry1Ab Bacillus thuringiensis Toxin in Ostrinia nubilalis (Lepidoptera: Crambidae)" (2006). Faculty Publications: Department of Entomology. 51.

https://digitalcommons.unl.edu/entomologyfacpub/51

This Article is brought to you for free and open access by the Entomology, Department of at DigitalCommons@University of Nebraska - Lincoln. It has been accepted for inclusion in Faculty Publications: Department of Entomology by an authorized administrator of DigitalCommons@University of Nebraska - Lincoln. 
This article is the copyright property of the Entomological Society of America and may not be used for any commercial or other private purpose without specific written permission of the Entomological Society of America. 


\title{
Inheritance of Resistance to the CrylAb Bacillus thuringiensis Toxin in Ostrinia nubilalis (Lepidoptera: Crambidae)
}

\author{
A. P. ALVES, T. A. SPENCER, B. E. TABASHNIK, ${ }^{1}$ and B. D. SIEGFRIED ${ }^{2}$ \\ Department of Entomology, University of Nebraska, Lincoln, NE 68583-0816
}

\begin{abstract}
J. Econ. Entomol. 99(2): 494-501 (2006)
ABSTRACT Laboratory selection with CrylAb, the predominant Bacillus thuringiensis ( $\mathrm{Bt}$ ) toxin in transgenic corn, Zea mays L., produced $>1000$-fold resistance in two laboratory strains of European corn borer, Ostrinia nubilalis (Hübner). We tested the offspring of various crosses to determine the mode of inheritance of resistance to Cryl Ab. Patterns of inheritance of resistance were similar in the two resistant strains. The progeny of reciprocal $F_{1}$ crosses (resistant male $\times$ susceptible female and vice versa) responded alike in bioassays, indicating autosomal inheritance. The median lethal concentrations $\left(\mathrm{LC}_{50}\right.$ values) of $\mathrm{F}_{1}$ were intermediate between the resistant and susceptible parents, indicating approximately additive inheritance. However, the dominance of resistance increased as the concentration of CrylAb decreased. Analysis of progeny from backcrosses $\left(\mathrm{F}_{1} \times\right.$ susceptible strain $)$ suggests that resistance was controlled by more than one locus. In particular, the fit of observed to expected mortality improved as the number of putative loci increased from 1 to 10 . The polygenic nature of resistance in these two laboratory strains suggests that major genes for resistance to Cryl $\mathrm{Ab}$ were not common in the founding populations of $O$. nubilalis. A low initial frequency of major genes for Cryl Ab resistance might be an important factor in delaying evolution of resistance to Bt corn in this pest.
\end{abstract}

KEY WORDS Ostrinia nubilalis, inheritance, resistance, transgenic corn

Insecticidal proteins from Bacillus thuringiensis (Bt) are useful in insect pest control, both in spray formulations and transgenic crops (Schnepf et al. 1998, Shelton et al. 2002). Despite the benefits of transgenic plants producing Bt toxins, their widespread use could cause evolution of resistance in target pests (McGaughey and Whalon 1992, Tabashnik 1994, Gould 1998, ILSI/HESI 1998, Ferré and Van Rie 2002, Bates et al. 2005). Although field-evolved resistance to Bt crops has not yet been detected, resistance to the $\mathrm{Bt}$ toxins in foliar sprays has evolved in field populations of diamondback moth, Plutella xylostella (L.), and in greenhouse populations of Trichoplusia ni (Hübner) (Janmaat and Myers 2003, Tabashnik et al. 2003).

Bt corn (Zea mays L.), which accounted for $32 \%$ of U.S. corn acreage in 2004 (ERS 2004), is useful for managing European corn borer, Ostrinia nubilalis (Hübner), a major corn pest (Mason et al. 1996). Resistance to $\mathrm{Bt}$ toxins in $O$. nubilalis has been reported in laboratory-selected strains exposed to the $\mathrm{Bt}$ formulation Dipel (Huang et al. 1997) and to the single toxins Cry1Ac (Bolin et al. 1999) and Cry1Ab (Chaufaux et al. 2001). Inheritance of resistance to Dipel is reported as autosomal, partially dominant, and is con-

\footnotetext{
${ }^{1}$ Department of Entomology, University of Arizona, Tucson, AZ 85721 .

${ }^{2}$ Corresponding author, e-mail: bsiegfried1@unl.edu.
}

trolled primarily by a single gene (Huang et al. 1999). Although CrylAb is the most abundant Cryl toxin in Dipel, this formulation also contains CrylAa, CrylAc, and other materials (Liu et al. 1996).

Because CrylAb has been the predominant toxin produced by Bt corn, we have focused on resistance of $O$. nubilalis to this toxin. Laboratory selection with CrylAb protoxin yielded significant levels of resistance in two strains after 7-10 generations (Chaufaux et al. 2001). Here, we analyzed inheritance of Cry1Ab resistance in these laboratory-selected strains after additional selection yielded $>1000$-fold resistance. Specific objectives were to determine sex linkage and dominance and to estimate the number of loci (one or multiple loci) involved in the resistance.

\section{Materials and Methods}

Insect Strains. We studied four strains of O. nubilalis: Europe-S, Europe-R, Nebraska-S, and RSTT-R. The parental Europe strain originated in 1993 from the Lombardia region of northern Italy and was divided into the unselected strain Europe-S and the selected strain Europe-R (Chaufaux et al. 2001). The same procedure was applied to the parental Nebraska strain, which originated in 1995 from Saunders County, Nebraska (Chaufaux et al. 2001). The RSTT-R strain was created by combining at least 200 egg masses from the 
Europe- $\mathrm{R}$ strain $\left(\mathrm{F}_{28}\right)$ with at least 200 egg masses from the Nebraska-R strain $\left(\mathrm{F}_{10}\right)$ (Siqueira et al. 2004b). When the inheritance experiments were initiated, the resistant strains (Europe-R and RSTT-R) had been selected by incorporation of CrylAb protoxin in the larval diet for at least 45 generations (Chaufaux et al. 2001, Siqueira et al. 2004a), and the susceptible strains (Europe-S and Nebraska-S) had been reared without exposure to insecticides for at least 75 generations.

Rearing. Rearing methods for O. nubilalis were based on those developed at the USDA-ARS Corn Insect Research Unit, Ames, IA (Guthrie et al. 1965, Lewis and Lynch 1969), as described by Siqueira et al. (2004b).

Bioassays. O. nubilalis neonates $(<24 \mathrm{~h}$ after hatching) were exposed to toxin on the surface of artificial diet (Marçon et al. 2000). The toxin used for bioassays was the purified trypsin-resistant core (TRC) of CrylAb from B. thuringiensis Berliner subsp. kurstaki provided by Monsanto Co. (St. Louis, MO), referred to hereafter as Cryl $\mathrm{Ab}$ toxin.

The rearing diet developed for Heliothis virescens (F.) (King et al. 1985) and adapted for O. nubilalis (Marçon et al. 1999) was used in place of $O$. nubilalis diet for Bt bioassays. Bioassays were performed in 128-well trays (each well $16 \mathrm{~mm}$ in diameter, $16 \mathrm{~mm}$ in height, CD International, Pitman, NJ). Approximately $1 \mathrm{ml}$ of diet was dispensed into each well and allowed to solidify. Seven concentrations of toxin were used. Dilutions were made in $0.1 \%$ Triton-X 100 nonionic detergent to obtain uniform spreading on the diet surface. Each well was surface treated with $30 \mu \mathrm{l}$ of the appropriate solution. Control treatments consisted of diet surface treated with $0.1 \%$ Triton X-100 only. Wells were allowed to air dry, and one neonate was randomly transferred into each well. Wells were then covered with vented lids (CD International), and trays were held in an incubator at $27^{\circ} \mathrm{C}, 24$-h scotophase, and $80 \% \mathrm{RH}$. Mortality was recorded $7 \mathrm{~d}$ after treatment. Larvae that had not grown beyond the first instar and weighed $\leq 0.1 \mathrm{mg}$ were considered dead. As a result, the criteria for "mortality" used in this study accounts for both severe growth inhibition and death. Control mortality never exceeded $10 \%$. In each experiment, bioassays were replicated at least three times for each strain or cross, with 16 larvae per concentration (total of at least 48 larvae per concentration per strain or cross)

Inheritance Experiments. To evaluate sex linkage and dominance, we tested $F_{1}$ progeny from two sets of reciprocal mass crosses between resistant and susceptible strains: Europe- $\mathrm{R}_{\mathrm{F} 83} \times$ Nebraska-S $\mathrm{S}_{\mathrm{F} 55}$ and RSTT$\mathrm{R}_{\mathrm{F} 55} \times$ Europe- $\mathrm{S}_{\mathrm{F} 94}$. For these experiments, the resistant strains were not selected for at least one generation before establishing the crosses. The pupae were sexed so that virgin males from one strain would mate with virgin females from the other, and vice versa. In all experiments, reciprocal mass crosses were established with $60-100$ pairs. To estimate the number of loci influencing resistance, $\mathrm{F}_{1}$ progeny from reciprocal crosses were backcrossed to the susceptible strains and tested for susceptibility to CrylAb as described above.

Data Analysis. Concentration-mortality data were analyzed by probit regression using POLO-PC (LeOra Software 1987) to calculate median lethal concentrations $\left(\mathrm{LC}_{50}\right.$ values) and their $95 \%$ fiducial limits and slopes and their standard errors. $\mathrm{LC}_{50}$ values were considered significantly different if no overlap occurred between their $95 \%$ fiducial limits. Mortality was corrected for control mortality using the method of Abbott (1925).

We calculated degree of dominance $(D)$ and its standard error based on $\mathrm{LC}_{50}$ values (Lehmann 1966, Stone 1968). We calculated effective dominance $(h)$ at specific concentrations (Liu and Tabashnik 1997, Bourguet et al. 2000) with mortality at each concentration estimated from concentration-mortality probit regression lines. $D$ varies from -1 (recessive) to 1 (dominant), with 0 indicating codominance (additive inheritance); $h$ varies from 0 (recessive) to 1 (dominant), with 0.5 indicating codominance. Comparisons between $D$ and $h$ were made using the formula $h^{\prime}=$ $(D+1) / 2$ (Liu and Tabashnik 1997, Bourguet et al. 2000)

The backcross generation obtained from mating $F_{1}$ offspring with parental susceptible strains was tested to estimate the number of genes affecting resistance by using the method of Lande (1981) and indirect tests of models with one, two, five and 10 loci (Tabashnik et al. 1992). The minimum number of independently segregating genes with equal effect contributing to resistance was estimated according to Lande's method as adapted by Tabashnik et al. (1992). With this method, if resistance is controlled by a single locus, a large increase in genetic variation is expected in backcross progeny relative to parental strains and their $\mathrm{F}_{1}$ progeny. As the number of loci increases, decreases are expected in the extra genetic variation in backcross progeny relative to parental strains and their $F_{1}$ progeny. The slope of concentration-mortality lines is inversely related to variance (Tabashnik 1991, Tabashnik et al. 1992). Thus, relative to slopes for parental strains and their $F_{1}$ progeny, a large decrease in slope for backcross progeny indicates monogenic inheritance, whereas smaller decreases suggest that multiple loci are involved.

In the indirect tests of monogenic and polygenic models, we tested the fit between observed mortality and mortality predicted by models with one, two, five, and 10 loci. This approach follows the one described by Tabashnik et al. (1992, 2002), except that backcrosses were done with the susceptible parental strains. The slopes of concentration-response lines for the parental strains were calculated as the mean of the slopes experimentally determined for each parental strain. For example, we used a slope of 2.0 for indirect tests when the slopes of the parental strains in the backcross were 2.2 (susceptible) and $1.8\left(\mathrm{~F}_{1}\right)$. We assumed that each locus had one allele conferring resistance $(\mathrm{R})$ and the other conferring susceptibility (S). We also assumed equal and additive effects of loci in polygenic models. The expected mortality for each 
Table 1. Responses to CrylAb of susceptible, resistant, $F_{1}$, and backeross larvae of $O$. nubilalis

\begin{tabular}{|c|c|c|c|c|c|}
\hline Strain or Cross & Generation & $n$ & Slope $\pm \mathrm{SE}$ & $\mathrm{LC}_{50}(95 \% \mathrm{FL})^{a}$ & $\mathrm{RR}^{b}$ \\
\hline \multicolumn{6}{|c|}{ Europe-R $\times$ Nebraska-S } \\
\hline Nebraska-S & 76 & 511 & $2.2 \pm 0.2$ & $2.8(2.3-3.4)$ & 5.6 \\
\hline Europe-R & 95 & 512 & $1.0 \pm 0.1$ & $1,000(590-1,600)$ & 2,000 \\
\hline $\mathrm{R} \sigma \times \mathrm{S}$ 우 & $\mathrm{F}_{1}$ & 512 & $2.5 \pm 0.2$ & $40(19-80)$ & 78 \\
\hline $\mathrm{R}$ 우 $\times \mathrm{S} \delta \hat{~}$ & $\mathrm{~F}_{1}$ & 510 & $3.1 \pm 0.3$ & $34(30-41)$ & 67 \\
\hline $\mathrm{R} \times \mathrm{S}($ pooled $)$ & $\mathrm{F}_{1}$ & 1,022 & $2.7 \pm 0.2$ & $37(27-50)$ & 73 \\
\hline $\mathrm{S} \times \mathrm{F}_{1}$ & $\mathrm{~F}_{2}$ & 1,024 & $2.4 \pm 0.2$ & $18(13-24)$ & 35 \\
\hline \multicolumn{6}{|l|}{ RSTT-R $\times$ Europe-S } \\
\hline Europe-S & 84 & 767 & $1.4 \pm 0.1$ & $0.51(0.34-0.71)$ & 1 \\
\hline RSTT-R & 56 & 763 & $1.5 \pm 0.1$ & $640(380-1,200)$ & 1,300 \\
\hline $\mathrm{R} \delta \hat{~} \times \mathrm{S}$ ㅇ & $\mathrm{F}_{1}$ & 765 & $3.4 \pm 0.4$ & $37(32-43)$ & 72 \\
\hline $\mathrm{R}$ 우 $\times \mathrm{S} \delta$ & $\mathrm{F}_{1}$ & 765 & $2.8 \pm 0.2$ & $35(22-54)$ & 68 \\
\hline $\mathrm{R} \times \mathrm{S}($ pooled $)$ & $\mathrm{F}_{1}$ & 1,530 & $3.0 \pm 0.2$ & $36(28-45)$ & 70 \\
\hline $\mathrm{S} \times \mathrm{F}_{1}$ & $\mathrm{~F}_{2}$ & 512 & $1.8 \pm 0.1$ & $9(5-18)$ & 19 \\
\hline
\end{tabular}

${ }^{a}$ Units are nanograms of CrylAb per square centimeter of diet with $95 \%$ fiducial limits in parentheses

${ }^{b} \mathrm{RR}$, resistance ratio $=\mathrm{LC}_{50}$ of strain or cross divided by $\mathrm{LC}_{50}$ of Europe-S (most susceptible strain).

concentration under each hypothesis was estimated as the cumulative probability from the appropriate tolerance distributions for each model (PROBNORM, SAS Institute 2001). The average absolute difference between observed and expected mortality was calculated as the mean of the absolute values of expected percentage mortality minus the observed percentage mortality for each concentration (Tabashnik et al. 1992).

\section{Results}

Resistance Levels, Maternal Effects, Sex Linkage, and Dominance. Relative to the susceptible Europe-S strain, $\mathrm{LC}_{50}$ values of CrylAb toxin were 2,000-fold higher for Europe-R and 1,300-fold higher for RSTT-R (Table 1; Fig. 1). The $\mathrm{LC}_{50}$ values did not differ significantly between the two resistant strains (Table 1).

For $\mathrm{F}_{1}$ progeny from Europe- $\mathrm{R} \times$ Nebraska-S and RSTT-R $\times$ Europe-S, the LC $_{50}$ values did not differ significantly between the $F_{1}$ progeny of the two reciprocal crosses (Table 1). Thus, inheritance was autosomal, and maternal effects and sex linkage were not evident. For each resistant strain, the $L_{50}$ for the $F_{1}$ progeny pooled from reciprocal crosses was significantly greater than the $\mathrm{LC}_{50}$ for the susceptible pa- rental strain and significantly less than the $\mathrm{LC}_{50}$ for the resistant parental strain (Table 1 ). Based on $\mathrm{LC}_{50}$ values for the parental strains and the pooled $\mathrm{F}_{1}$ progeny, degree of dominance $(D \pm \mathrm{SE})$ was $-0.12 \pm 0.49$ $\left(h^{\prime}=0.45\right)$ for Europe-R and $0.19 \pm 0.38\left(h^{\prime}=0.59\right)$ for RSTT-R, which are both close to additive inheritance. For both resistant strains, effective dominance (h) varied widely with concentration, from dominant inheritance at low concentrations to recessive inheritance at high concentrations (Table 2).

Number of Genes. Results from two different methods to test for the number of genes responsible for resistance suggest that resistance was not controlled by a single major gene in either resistant strain (Figs. 2-4; Table 3). For both resistant strains, analysis by Lande's method implies that many loci affected resistance. Lande's method yielded an estimate of $\geq 20$ for the minimum number of independently segregating loci with equal effect contributing to the difference in susceptibility between the RSTT-R and Europe-S strains. For the Europe-R strain, a specific estimate for the minimum number of genes could not be calculated because the slope for the backcross progeny (2.4) was not lower than the slopes for the parental and $F_{1}$ strains $($ mean $=2.0$; Table 1$)$. Because slope is inversely related to variance, this indicates no extra
RSTT-R $\times$ Europe-S

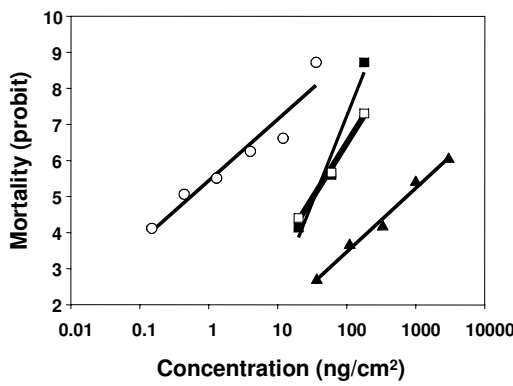

Europe-R x Nebraska-S

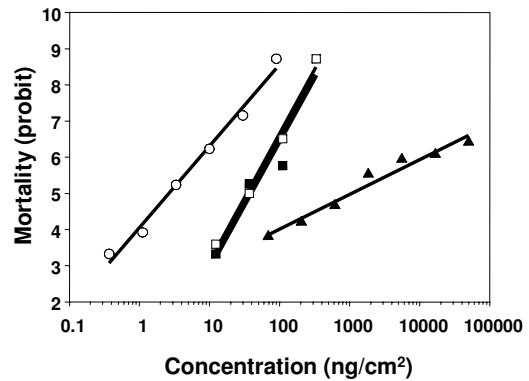

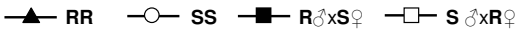

Fig. 1. Reciprocal crosses of the RSTT-R and Europe-R resistant colonies. 
Table 2. Effective dominance $(h)$ of resistance to CrylAb in O. nubilalis larvae

\begin{tabular}{|c|c|c|c|c|c|c|c|c|c|}
\hline $\begin{array}{c}\text { Concn } \\
\left(\mathrm{ng} / \mathrm{cm}^{2}\right)\end{array}$ & Strain or cross & $\begin{array}{c}\% \\
\text { survival }\end{array}$ & Fitness $^{a}$ & $h^{b}$ & $\begin{array}{c}\text { Concn } \\
\left(\mathrm{ng} / \mathrm{cm}^{2}\right)\end{array}$ & Strain or cross & $\begin{array}{c}\% \\
\text { survival }\end{array}$ & Fitness $^{a}$ & $h^{b}$ \\
\hline \multicolumn{6}{|c|}{ Europe-R $\times$ Nebraska-S } & \multicolumn{4}{|c|}{ RSTT-R $\times$ Europe-S } \\
\hline \multirow[t]{3}{*}{5} & Nebraska-S & 29.12 & 0.29 & & 5 & Europe-S & 8.85 & 0.09 & \\
\hline & Europe-R & 99.04 & 1 & & & RSTT-R & 100 & 1 & \\
\hline & $\mathrm{F}_{1}$ & 99.06 & 1.00 & 1.00 & & $\mathrm{~F}_{1}$ & 99.43 & 0.99 & 0.99 \\
\hline \multirow[t]{3}{*}{20} & Nebraska-S & 3.07 & 0.03 & & 20 & Europe-S & 1.54 & 0.02 & \\
\hline & Europe-R & 95.82 & 1 & & & RSTT-R & 98.93 & 1 & \\
\hline & $\mathrm{F}_{1}$ & 76.73 & 0.80 & 0.79 & & $\mathrm{~F}_{1}$ & 77.04 & 0.78 & 0.78 \\
\hline \multirow[t]{3}{*}{40} & Nebraska-S & 0.57 & 0.01 & & 40 & Europe-S & 0.51 & 0.01 & \\
\hline & Europe-R & 92.22 & 1 & & & RSTT-R & 96.71 & 1 & \\
\hline & $\mathrm{F}_{1}$ & 46.41 & 0.50 & 0.50 & & $\mathrm{~F}_{1}$ & 44.04 & 0.46 & 0.45 \\
\hline \multirow[t]{3}{*}{100} & Nebraska-S & 0 & 0 & & 100 & Europe-S & 0 & 0 & \\
\hline & Europe-R & 84.61 & 1 & & & RSTT-R & 89.07 & 1 & \\
\hline & $\mathrm{F}_{1}$ & 12.3 & 0.15 & 0.15 & & $\mathrm{~F}_{1}$ & 9.18 & 0.10 & 0.10 \\
\hline \multirow[t]{3}{*}{600} & Nebraska-S & 0 & 0 & & 400 & Europe-S & 0 & 0 & \\
\hline & Europe-R & 59.1 & 1 & & & RSTT-R & 62.17 & 1 & \\
\hline & $\mathrm{F}_{1}$ & 0 & 0 & 0 & & $\mathrm{~F}_{1}$ & 0 & 0 & 0 \\
\hline
\end{tabular}

${ }^{a}$ Fitness of RR is defined as 1 (Liu and Tabashnik 1997); fitness of SS is defined as percentage of survival SS divided by percentage of survival $\mathrm{RR}$ at the same toxin concentration; fitness of RS is defined as percentage of survival RS divided by percentage of survival RR at the same toxin concentration. Adjusted mortality was calculated before fitness calculation, and percentage of survival $=100 \%-$ mortality $($ expressed as percentage).

${ }^{b} h=\left(w_{12}-w_{22}\right) /\left(w_{11}-w_{22}\right)$, where $w_{11}, w_{12}$, and $w_{22}$ represent fitness values at a particular toxin concentration for RR, RS, and SS, respectively. $h$ varies from 0 to $1, h=0$ indicates complete recessive, $h=1$ indicates complete dominance, and $h=0.5$ indicates intermediate dominance (codominance).

genetic variation was seen in the backcross progeny relative to the parental and $\mathrm{F}_{1}$ strains, which suggests resistance in Europe-R was controlled by many loci (see Materials and Methods).

For both resistant strains, results of indirect tests show that the difference between observed and expected mortality decreased as the number of loci in the model increased (Table 3; Figs. 3 and 4). The average absolute difference between observed and expected mortality was highest for the one-locus model and lowest for the 10-locus model (Europe-R = $9.5 \%$ for one locus versus $3.6 \%$ for 10 loci, RSTT-R $=$ $16.5 \%$ for one locus versus $3.4 \%$ for 10 loci; Table 3 ). Consistent with results from the Lande's test described above, results from indirect tests of the monogenic model show poor fit with the data. With indirect tests of the monogenic model, significant deviation occurred at three of seven concentrations for Europe-R and six of seven concentrations for RSTT-R (Table 3). In contrast, significant deviation from the 10-locus model occurred at only one concentration for Europe-R and none for RSTT-R (Table 3).

\section{Discussion}

As far as we know, the levels of resistance to CrylAb in the laboratory-selected strains studied here $(2,000$ fold for Europe-R and 1,300-fold for RSTT-R; Table 1) are the highest levels of resistance to a CrylA toxin ever reported for $O$. nubilalis. Previous reports from other laboratory-selected strains of this pest include up to 160-fold resistance to CrylAc in the S-I strain from Minnesota (Bolin et al. 1999) and 520-fold resistance to CrylAc in the KS-SC strain from Kansas (Li et al. 2005a). Factors contributing to the differences in reported resistance levels among strains may
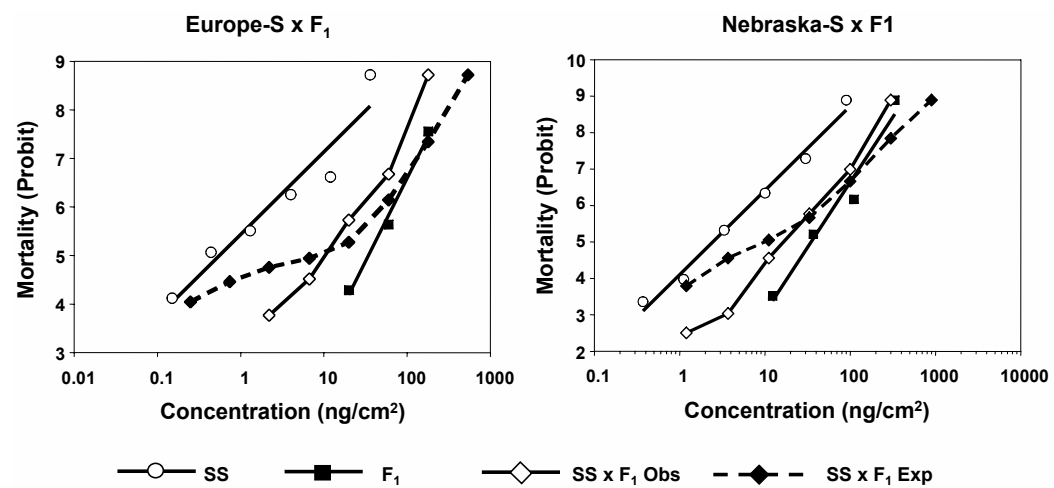

Fig. 2. Backcrosses of the Europe-S and Nebraska-S susceptible colonies with the $\mathrm{F}_{1}$ offspring. Expected \% mortality at concentration $x=0.5 \times\left(\%\right.$ mortality of $\mathrm{F}_{1}$ at $x+\%$ mortality of SS at $\left.x\right)$, obtained from regression lines of parental strains. 

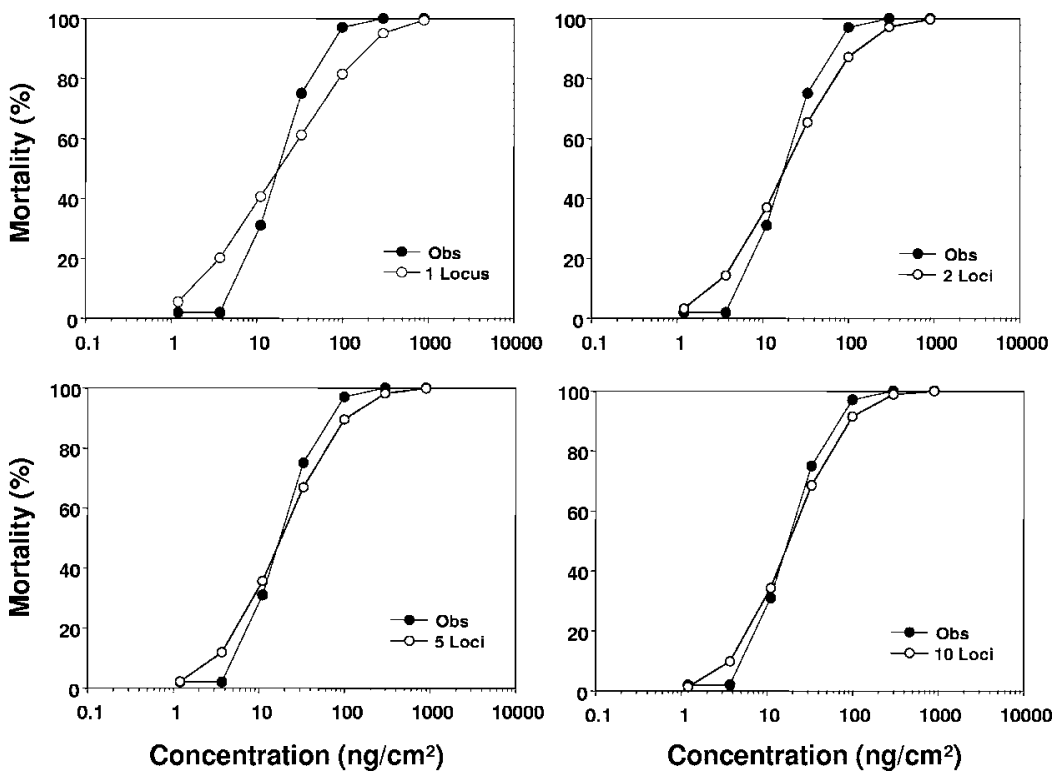

Fig. 3. Observed versus expected mortality at each of five concentrations tested of B. thuringiensis TRC Cry1Ab for O. nubilalis larvae from the backcross $\mathrm{F}_{1}($ Europe- $\mathrm{R} \times$ Nebraska-S $) \times$ Nebraska-S.

include genetic differences among the strains as well as differences among experiments in the toxic materials tested, bioassay procedures, and susceptibility among the unselected strains used for calculating resistance ratios. Side-by-side comparisons among strains with identical methods could clarify the role of genetic versus environmental influences (GonzálezCabrera et al. 2001).

The results reported here show similar levels and inheritance of resistance to CrylAb toxin in the Eu-
rope-R and RSTT-R strains. Although the resistance ratio was somewhat higher for the Europe-R strain, no significant difference occurred between resistant strains in $\mathrm{LC}_{50}$ of CrylAb (Table 1). When the RSTT-R strain was created by pooling individuals from Nebraska-R $\left(\mathrm{F}_{10}\right)$ and Europe-R $\left(\mathrm{F}_{28}\right)$, the Europe-R strain was much more resistant than Nebraska-R (Siqueira et al. $2004 b$ ). Because Europe-R may be a primary source of the resistance alleles in RSTT-R, similarity between Europe- $\mathrm{R}$ and RSTT-R is not unexpected.
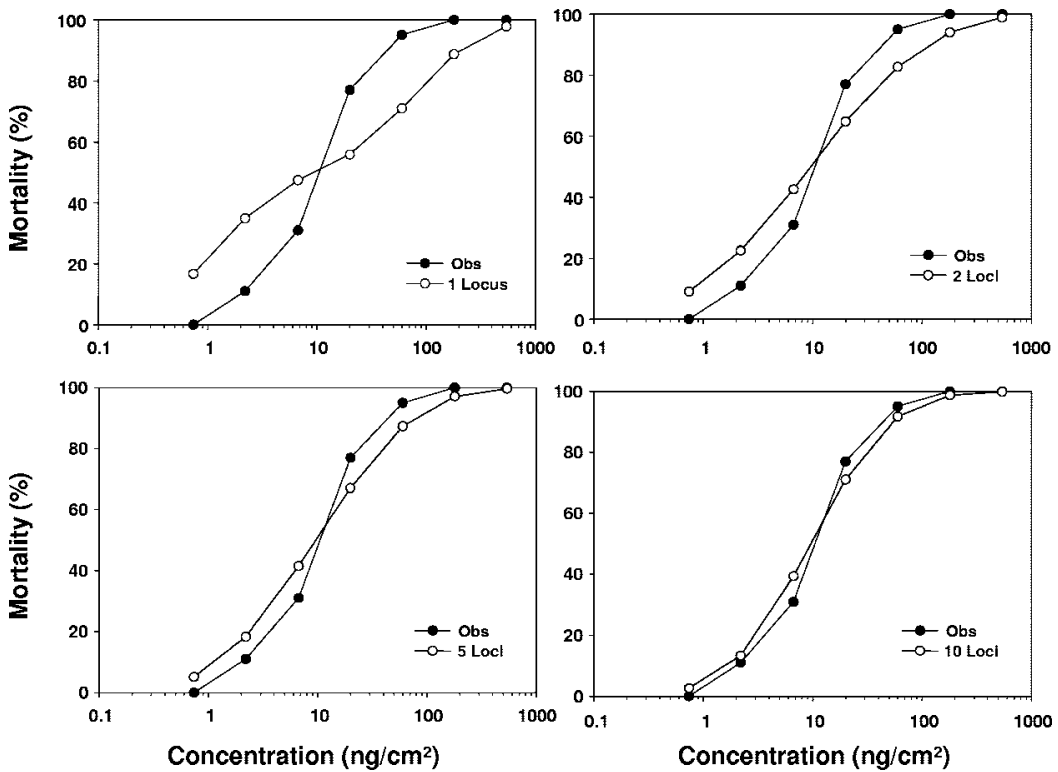

Fig. 4. Observed versus expected mortality at each of five concentrations tested of B. thuringiensis TRC CrylAb for O. nubilalis larvae from the backcross $\mathrm{F}_{1}($ RSTT-R $\times$ Europe-S $) \times$ Europe-S. 
Table 3. Indirect tests for deviation between observed and expected mortality $($ df $=1)$ for monogenic and additive polygenic models

\begin{tabular}{|c|c|c|c|c|c|c|c|c|}
\hline \multirow{3}{*}{ Concn $\left(\mathrm{ng} / \mathrm{cm}^{2}\right)$} & \multicolumn{8}{|c|}{ Genetic model } \\
\hline & \multicolumn{2}{|c|}{1 locus } & \multicolumn{2}{|c|}{2 loci } & \multicolumn{2}{|c|}{5 loci } & \multicolumn{2}{|c|}{10 loci } \\
\hline & $\chi^{2}$ & $P$ & $\chi^{2}$ & $P$ & $\chi^{2}$ & & $\chi^{2}$ & $P$ \\
\hline \multicolumn{9}{|l|}{ Europe-R $\times$ Nebraska-S } \\
\hline 1.2 & 1.52 & 0.218 & 0.32 & 0.572 & 0.00 & 1.000 & 0.18 & 0.671 \\
\hline 3.7 & 13.10 & $<0.001^{a}$ & 7.96 & $0.005^{a}$ & 5.98 & $0.014^{a}$ & 4.40 & $0.036^{a}$ \\
\hline 11.1 & 2.47 & 0.116 & 0.99 & 0.320 & 0.60 & 0.439 & 0.30 & 0.584 \\
\hline 33.3 & 5.20 & $0.023^{a}$ & 2.66 & 0.103 & 1.90 & 0.168 & 1.26 & 0.262 \\
\hline 100 & 10.23 & $0.001^{a}$ & 5.61 & $0.018^{a}$ & 3.86 & $0.049^{a}$ & 2.52 & 0.112 \\
\hline 300 & 3.36 & 0.067 & 1.93 & 0.165 & 1.21 & 0.271 & 0.78 & 0.377 \\
\hline 900 & 0.42 & 0.517 & 0.22 & 0.639 & 0.11 & 0.740 & 0.05 & 0.823 \\
\hline Avg. mortality (\%) & 58 & & 58 & & 58 & & 58 & \\
\hline Mean difference $(\%)$ & 9.5 & & 6.1 & & 4.6 & & 3.6 & \\
\hline \multicolumn{9}{|l|}{ RSTT-R $\times$ Europe-S } \\
\hline 0.74 & 10.35 & $0.001^{a}$ & 5.11 & $0.024^{a}$ & 2.85 & 0.091 & 1.46 & 0.227 \\
\hline 2.2 & 12.59 & $<0.001^{a}$ & 3.94 & $0.047^{a}$ & 1.97 & 0.160 & 0.35 & 0.554 \\
\hline 6.7 & 5.25 & $0.022^{a}$ & 2.72 & 0.099 & 2.27 & 0.132 & 1.49 & 0.222 \\
\hline 20 & 8.89 & $0.003^{a}$ & 3.29 & 0.070 & 2.30 & 0.129 & 0.96 & 0.327 \\
\hline 60 & 14.15 & $<0.001^{a}$ & 5.46 & $0.019^{a}$ & 2.90 & 0.089 & 0.89 & 0.345 \\
\hline 180 & 6.74 & $0.009^{a}$ & 3.33 & 0.068 & 1.63 & 0.202 & 0.75 & 0.386 \\
\hline 540 & 1.31 & 0.252 & 0.65 & 0.420 & 0.22 & 0.639 & 0.07 & 0.791 \\
\hline Avg. mortality (\%) & 59 & & 59 & & 59 & & 59 & \\
\hline Mean difference $(\%)$ & 16.5 & & 9.1 & & 6.3 & & 3.4 & \\
\hline
\end{tabular}

${ }^{a}$ Probability values indicating significant differences between the observed and expected mortality $(P<0.05)$.

Analysis of the $\mathrm{F}_{1}$ progeny from reciprocal crosses between the resistant and susceptible strains indicates that resistance to CrylAb was inherited as an autosomal trait in both the RSTT-R and Europe-R strains. These results are consistent with nearly all previous results with Bt resistance (Ferré and Van Rie 2002), including resistance to Dipel in the KS-SC strain of O. nubilalis (Huang et al. 1999).

For both resistant strains, $D$ was close to zero, indicating that the $\mathrm{LC}_{50}$ values of $\mathrm{F}_{1}$ hybrid progeny were intermediate between the $\mathrm{LC}_{50}$ values of resistant and susceptible parent strains. $h$ depended on the concentration of the toxin, with resistance more dominant as concentration decreased. Increased dominance of Bt resistance at low toxin concentrations has been reported in several other species (Liu and Tabashnik 1997, Sayyed et al. 2000, Liu et al. 2001, Tabashnik et al. 2004).

Two different methods for analyzing the response of backcross offspring provide evidence that more than one locus contributed to resistance. In tests of models with one, two, five and 10-locus, the fit was best to 10-loci models for both resistant strains (Table 3; Figs. 3 and 4). Analysis by Lande's method suggests that a large number of independently segregating loci affected resistance in both strains. It should be noted that both these tests provide only indirect evidence for involvement of multiple loci of equal and additive effects. Linkage mapping with Europe-R and RSST-R would enable a direct test of polygenic inheritance of resistance to CrylAb, as inferred from analysis of backcross offspring reported here. Although sequence variation in the cadherin gene of $O$. nubilalis has been reported (Coates et al. 2005), linkage to resistance has not yet been reported.

It seems that the genetic basis and mechanism of resistance differ between the strains studied here and the KS-SC strain of $O$. nubilalis. The results with Europe-R and RSTT-R differ from the conclusion that resistance to Dipel in KS-SC is controlled primarily by one gene (Huang et al.1999). Furthermore, resistance in KS-SC was higher to CrylAb protoxin (254-fold) than to trypsin-activated CrylAb toxin (12-fold) (Li et al. 2005b), whereas both strains studied here showed greater resistance to Cry1Ab toxin (108- and 484-fold) than protoxin (6- and 15-fold) (Siqueira et al. 2004a). Thus, reduced protoxin activation seems to be a major mechanism of resistance in KS-SC (Li et al. 2005b) but not in Europe-R or RSTT-R (Siqueira et al. 2004a).

Unlike the two CrylAb-resistant strains of O. nubilalis tested here, none of the four Bt-resistant strains of other lepidopteran species previously analyzed for fit to models with one, two, or more loci showed better fit as the number of loci increased. Diamondback moth resistance to Dipel in the NO-QA strain from Hawaii (Tabashnik et al. 1992) and to Javelin (a formulation similar to Dipel) in the Loxa A strain from Florida (Tang et al. 1997) fit best to a one-locus model. Subsequent molecular work with the NO-QA strain mapped genetic control of its CrylA resistance to a single chromosomal location (Heckel et al. 1999). With pink bollworm resistance to CrylAc in the AZP-R strain from Arizona, the best fit occurred with one- or two-locus models (Tabashnik et al. 2002), and molecular work identified a cadherin locus tightly linked with high levels of resistance. Diamondback moth resistance to Cry $1 \mathrm{C}$ in the CrylC-Sel strain from South Carolina fit best to a one-locus model (Zhao et al. 2000), and subsequent molecular mapping with a related strain $(\mathrm{SCl})$ revealed contributions from two linkage groups (Baxter et al. 2005).

Evidence from several independent research groups suggests that major genes conferring high levels of resistance to CrylAb are rare in O. nubilalis. In 
$\mathrm{F}_{2}$ screens of 1,418 isofemale lines (5,672 alleles) from field populations in the United States and France, no alleles for resistance to $\mathrm{Bt}$ corn that produces $\mathrm{Cryl} \mathrm{Ab}$ were detected (Andow et al. 1998, 2000; Bourguet et al. 2003). Although laboratory selection of $O$. nubilalis strains has yielded several strains with moderate levels of resistance (Huang et al. 1997, Bolin et al. 1999), we are not aware of any that are reported to complete development on CrylAb-producing corn (Huang et al. 2002). The resistance levels seen here for CrylAb are higher than those reported for other Bt-resistant strains of $O$. nubilalis, yet the results imply that the resistance is caused by more than one locus and that a major resistance allele was absent in the founding populations.

Although the strains studied here exhibit increased survival on CrylAb expressing leaf tissue, surviving larvae are extremely stunted and are unlikely to complete development (B.D.S., unpublished). The hypothesis that the resistance alleles occurring in laboratory-selected strains such as Europe-R and RSTT-R are relevant in the field can be tested only after resistance evolves in the field. So far, after $>9 \mathrm{yr}$ of large-scale use of Bt corn, field-evolved resistance to Bt toxins in O. nubilalis has not been documented. We hypothesize that a low initial frequency of major genes for resistance to Cry1 $\mathrm{Ab}$ has been a major factor helping to delay resistance to Bt corn in this pest.

\section{Acknowledgments}

We thank the Consortium for Plant Biotechnology Research and Syngenta Seeds for providing financial support, and Monsanto for providing the Cryl $\mathrm{Ab}$ toxin used in bioassays. This is journal series paper 14548, NE Agricultural Research Division and contribution No. 1216 of the Department of Entomology, University of Nebraska.

\section{References Cited}

Abbott, W. S. 1925. A method of computing the effectiveness of an insecticide. J. Econ. Entomol. 18: 265-267.

Andow, D. A., D. N. Alstad, Y.-H. Pang, P. C. Bolin, and W. D. Hutchison. 1998. Using an $\mathrm{F}_{2}$ screen to search for resistance alleles to Bacillus thuringiensis toxin in European corn borer (Lepidoptera: Crambidae). J. Econ. Entomol. 91: 572-578.

Andow, D. A., D. M. Olson, R. L. Hellmich, D. N. Alstad, and W. D. Hutchison. 2000. Frequency of resistance to $B a$ cillus thuringiensis toxin CrylAb in an Iowa population of European corn borer (Lepidoptera: Crambidae). J. Econ. Entomol. 93: 26-30.

Bates, S. L., J.-Z. Zhao, R. T. Roush, and A. M. Shelton. 2005. Insect resistance management in GM crops: past, present and future. Nat. Biotechnol. 23: 57-62.

Baxter, S. W., J.-Z., Zhao, L. J. Gahan, L. J., A. M. Shelton, A. M., B. E. Tabashnik and D. G. Heckel. 2005. Novel genetic basis of field-evolved resistance to $\mathrm{Bt}$ toxins in Plutella xylostella. Insect Mol. Biol. 14: 327-334.

Bolin, P. C., W. D. Hutchison, and D. A. Andow. 1999. Long-term selection for resistance to Bacillus thuringiensis CrylAc endotoxin in a Minnesota population of European corn borer (Lepidoptera: Crambidae). J. Econ. Entomol. 92: 1021-1030.
Bourguet, D., A. Genissel, and M. Raymond. 2000. Insecticide resistance and dominance levels. J. Econ. Entomol. 93: 1588-1595.

Bourguet, D., J. Chaufaux, M. Séquin, C. Buisson, J. L. Hinton, T. J. Stodola, P. Porter, G. Cronholm, L. L. Buschman, and D. A. Andow. 2003. Frequency of alleles conferring resistance to Bt maize in French and US corn belt populations of the European corn borer, Ostrinia nubilalis. Theor. Appl. Genet. 106: 1225-1233.

Chaufaux, J., M. Seguin, J. J. Swanson, D. Bourguet, and B. D. Siegfried. 2001. Chronic exposure of the European corn borer (Lepidoptera: Crambidae) to CrylAb Bacillus thuringiensis toxin. J. Econ. Entomol. 94: 1-7.

Coates, B. S., D. V. Sumerford, R. L. Hellmich, and L. C. Lewis. 2005. Sequence variation in the cadherin gene of Ostrinia nubilalis: a tool for field monitoring. Insect Biochem. Mol. Biol. 35: 129-139.

[ERS] Economic Research Service. 2004. Adoption of genetically engineered crops in the United States. Economic Research Service, Washington, DC. (http:// ers.usda.gov/data/BiotechCrops).

Ferré, J., and J. Van Rie. 2002. Biochemistry and genetics of insect resistance to Bacillus thuringiensis. Annu. Rev. Entomol. 47: 501-533.

González-Cabrera, J., S. Herrero, A. H. Sayyed, B. Escriche, Y. B. Liu, S. K. Meyer, D. J. Wright, B. E. Tabashnik, and J. Ferré. 2001. Variation in susceptibility to Bacillus thuringiensis toxins among unselected strains of Plutella xylostella. Appl. Environ. Microbiol. 67: 4657-4661.

Gould, F. 1998. Sustainability of transgenic insecticidal cultivars: integrating pest genetics and ecology. Annu. Rev. Entomol. 43: 701-726.

Guthrie, W. D., E. S. Raun, F. F. Dicke, G. R. Pesho, and S. W. Carter. 1965. Laboratory production of European corn borer egg masses. Iowa State J. Sci. 40: 665-683.

Heckel, D. G., L. J. Gahan, Y. B. Liu, and B. E. Tabashnik. 1999. Genetic mapping of resistance to Bacillus thuringiensis toxins in diamondback moth using biphasic linkage analysis. Proc. Natl. Acad. Sci. U.S.A. 96: 8373-8377.

Huang, F., R. A. Higgins, and L. L. Buschman. 1997. Baseline susceptibility and changes in susceptibility to Bacillus thuringiensis subsp. kurstaki under selection pressure in European corn borer (Lepidoptera: Pyralidae). J. Econ. Entomol. 90: 1137-1143.

Huang, F., L. L. Buschman, R. A. Higgins, and W. H. McGaughey. 1999. Inheritance of resistance to Bacillus thuringiensis toxin (Dipel ES) in the European corn borer. Science (Wash. DC) 284: 965-967.

Huang, F., L. L. Buschman, R. A. Higgins, and H. Li. 2002. Survival of Kansas Dipel-resistant European corn borer (Lepidoptera: Crambidae) on Bt and non-Bt corn hybrids. J. Econ. Entomol. 95: 614-621.

[ILSI/HESI] International Life Sciences Institute/Health and Environmental Sciences Institute. 1998. An evaluation of insect resistance management in Bt field corn: a science-based framework for risk assessment and risk management. Report of an ILSI HESI Expert Panel. ILSI, Washington, DC.

Janmaat, A. F., and J. H. Myers. 2003. Rapid evolution and the cost of resistance to Bacillus thuringiensis in greenhouse populations of cabbage loopers, Trichoplusia ni. Proc. R. Soc. Lond. B. 270: 2263-2270.

King, E. G., G. G. Hartley, D. F. Martin, and M. L. Laster. 1985. Large-scale rearing of a sterile backcross of the tobacco budworm (Lepidoptera: Noctuidae). J. Econ. Entomol. 78: 1166-1172. 
Lande, R. 1981. The number of genes contributing to quantitative variation between and within populations. Genetics 99: 541-553.

Lehmann, E. L. 1966. Testing statistical hypotheses. Wiley, New York.

LeOra Software. 1987. POLO-PC: a user's guide to probit and logit analysis computer program. LeOra Software, Berkeley, CA.

Lewis, L. C., and R. E. Lynch. 1969. Rearing the European corn borer on corn leaf and wheat germ diets. Iowa State J. Sci. 44: $9-14$

Li, H., B. Oppert, R. A. Higgins, F. Huang, L. L. Buschman, and K. Y. Zhu. 2005a. Susceptibility of Dipel-resistant and -susceptible Ostrinia nubilalis (Lepidoptera: Crambidae) to individual Bacillus thuringiensis protoxins. J. Econ. Entomol. 98: 1333-1340.

Li, H, B. Oppert, R. A. Higgins, F. Huang, L. L. Buschman, J-R Gao, and K. Y. Zhu. 2005b. Characterization of cDNAs encoding three trypsin-like proteinases and mRNA quantitative analysis in Bt-resistant and -susceptible strains of Ostrinia nubilalis. Insect Biochem. Mol. Biol. 35: 847-860.

Liu, Y. B., and B. E. Tabashnik. 1997. Inheritance of resistance to the Bacillus thuringiensis toxin CrylC in the diamondback moth. Appl. Environ. Microbiol. 63: 2218 2223.

Liu, Y. B., B. E. Tabashnik, and M. Pusztai-Carey. 1996. Field-evolved resistance to Bacillus thuringiensis toxin CryIC in diamondback moth (Lepidoptera: Plutellidae). J. Econ. Entomol. 80: 798-804.

Liu, Y. B., B. E. Tabashnik, T. J. Dennehy, A. L. Patin, M. A. Sims, S. K. Meyer, and Y. Carrière. 2001. Effects of Bt cotton and CrylAc toxin on survival and development of pink bollworm (Lepidoptera: Gelechiidae). J. Econ. Entomol. 94: 1237-1242.

Marçon, P.C.R. G., L. J. Young, K. L. Steffey, and B. D. Siegfried. 1999. Baseline susceptibility of European corn borer (Lepidoptera: Crambidae) to Bacillus thuringiensis toxins. J. Econ. Entomol. 92: 279-285.

Marcon, P.C.R.G., B. D. Siegfried, T. Spencer, and W. D. Hutchison. 2000. Development of diagnostic concentrations for monitoring Bacillus thuringiensis resistance in European corn borer (Lepidoptera: Crambidae). J. Econ. Entomol. 93: 925-930.

Mason, C. E., M. E. Rice, D. D. Calvin, J. W. Van Duyn, W. B. Showers, W. D. Hutchison, J. F. Witkowski, R. A. Higgins, D. W. Onstad, and G. P. Dively. 1996. European corn borer ecology and management. North Central Regional Extension Publication No. 327, Iowa State University, Ames, IA.

McGaughey, W. H., and M. E. Whalon. 1992. Managing insect resistance to Bacillus thuringiensis toxins. Science (Wash. DC) 258: 1451-1455.

SAS Institute. 2001. SAS user's guide: statistics, version 8.2 . SAS Institute, Cary, NC.

Sayyed, A. H., J. Ferré, and D. J. Wright. 2000. Mode of inheritance and stability of inheritance to Bacillus thuringiensis var. kurstaki in a diamondback moth (Plutella xylostella) population from Malaysia. Pest Manage. Sci. 56: 743-748.

Schnepf, E., N. Crickmore, J. van Rie, D. Lereclus, J. Baum, J. Feitelson, D. R. Zeigler, and D. H. Dean. 1998. Bacillus thuringiensis and its pesticidal crystal proteins. Microbiol. Mol. Biol. Rev. 62: 775-806.

Shelton, A. M., J.-Z. Zhao, and R. T. Roush. 2002. Economic ecological, food safety, and social consequences of the deployment of Bt transgenic plants. Annu. Rev. Entomol. 47: 845-881.

Siqueira, H.A.A., K. W. Nickerson, D. J. Moellenbeck, and B. D. Siegfried. 2004a. Activity of gut proteinases from CrylAb-selected colonies of the European corn borer, Ostrinia nubilalis (Lepidoptera: Crambidae). Pest Manage. Sci. 60: 1189-1196

Siqueira, H.A.A., T. Spencer, D. J. Moellenbeck, and B. D. Siegfried. 2004b. Cross-resistance of CrylAb-selected Ostrinia nubilalis (Hübner) (Lepidoptera: Crambidae) to Bacillus thuringiensis delta-endotoxins. J. Econ. Entomol. 97: 1049-1057.

Stone, B. F. 1968. A formula for determining degree of dominance in cases of monofactorial inheritance of resistance to chemicals. Bull. World Health Organ. 38: 325-326.

Tabashnik, B. E. 1991. Determining the mode of inheritance of pesticide resistance with backcross experiments. J. Econ. Entomol. 84: 703-712.

Tabashnik, B. E. 1994. Evolution of resistance to Bacillus thuringiensis. Annu. Rev. Entomol. 39: 47-79.

Tabashnik, B. E., J. M. Schwartz, N. Finson, and M. W. Johnson. 1992. Inheritance of resistance to Bacillus thuringiensis in diamondback moth (Lepidoptera: Plutellidae). J. Econ. Entomol. 85: 1046-1055.

Tabashnik, B. E., Y. B. Liu, T. J. Dennehy, M. A. Sims, M. S. Sisterson, R. W. Biggs, and Y. Carrière. 2002. Inheritance of resistance to Bt toxin CrylAc in field-derived strain of pink bollworm (Lepidoptera: Gelechiidae). J. Econ. Entomol. 95: 1018-1026.

Tabashnik, B. E., Y. Carrière, T. J. Dennehy, S. Morin, M. S. Sisterson, R. T. Roush, A. M. Shelton, and J.-Z. Zhao. 2003. Insect resistance to transgenic Bt crops: lessons from the laboratory and field. J. Econ. Entomol. 96: 10311038 .

Tabashnik, B. E., F. Gould, and Y. Carrière. 2004. Delaying evolution of insect resistance to transgenic crops by decreasing dominance and heritability. J. Evol. Biol. 17: 904-912.

Tang, J. D., S. Gilboa, R. T. Roush, and A. M. Shelton. 1997. Inheritance, stability, and lack-of-fitness costs of fieldselected resistance to Bacillus thuringiensis in diamondback moth (Lepidoptera: Plutellidae) from Florida J. Econ. Entomol. 90: 732-741.

Zhao, J. Z., H. L. Collins, J. D. Tang, J. Cao, E. D. Earle, R. T. Roush, S. Herrero, B. Escriche, J. Ferré, and A. M. Shelton. 2000. Development and characterization of diamondback moth resistance to transgenic broccoli expressing high levels of CrylC. Appl. Environ. Microbiol. 66: 3784-3789.

Received 20 May 2005; accepted 1 October 2005. 